\title{
Tertiary evolution of the West European Platform: \\ syn-kinematic stratigraphy and palaeogeography
}

\section{Preface}

This special publication documents two studies on the syn-orogenic Tertiary development of continental Western Europe. The study area comprises the region situated north of the Alpine and Pyrenean mountain chains and south of the North Sea and North German-Polish Lowland basins. Jointly, they present thus aspects of the geological history of the larger part of the West European Platform.

The first study examines the Middle Eocene to Pliocene tectonostratigraphy of the Alpine Foreland Basin and the European Cenozoic Rift System in conjunction with the plate-kinematic evolution of the adjoining western Mediterranean and eastern Atlantic domains. It is argued that the sequence stratigraphic architecture of the sedimentary fills of these basins reflects a tectonic episodicity, which is correlative with intermittent structural deformation and sediment accumulation in the AfricanEuropean plate-boundary zone. It is therefore concluded that the polyphase tectono-sedimentary history of the West European Platform was largely governed by the plate-tectonic motions of Africa, Apulia and Iberia relative to Europe.

The second study reviews the Middle Eocene to Pliocene palaeogeographic evolution of Western Europe in a corresponding plate-kinematic context. The episodic changes in tectonic activity during the Alpine orogeny, as driven by the convergence of Africa and Europe and the collision of the Apulian and Iberian microplates with the European Plate, determined larger-scale palaeogeographic configurations and palaeo-environmental conditions in combination with eustatic changes of sea level. Thus, the generally deep-water Alpine Foredeep opened and evolved into the overall shallow-water and terrestrial Alpine Molasse Basin in a causal relationship with the origin and formation of the Alps. At the same time, the palaeogeography of the adjacent West European Platform was modified by rifting. It is shown that, ultimately, continentalization of the platform occurred from the Middle Miocene onwards and that this progressive environmental change resulted in the establishment of the present-day river drainage systems.

W.J.E. van de Graaff

Guest Editor 